\title{
Six secrets to success-how to build a sustainable biotech business
}

\author{
Francesco De Rubertis, Roman Fleck \& Werner Lanthaler \\ What are the core elements of a successful biotech?
}

\begin{abstract}
— ach individual biotech business is unique: —founding entrepreneurs have their own visions, strategies and goals; the science and technology that drive companies is inherently exclusive; and every business is exposed to a wide range of external factors, risks and market forces. With that said, do successful biotechs share common characteristics?

Yes, they do, and this article looks at the main facets of sustainable and long-term biotech businesses. Of course, it always starts with the science, but then you'll need to focus on management, adaptation, timing, location and cash (Table 1).
\end{abstract}

\section{Management: the right team}

Having a strong, experienced and stable management team is essential to the success of any business, because venture capitalists (VCs) are investing in the people at the top rather than the assets, technology or product. Why? Because a good management team keeps a business working effectively and efficiently and sets out the company's values, visions, commitment and culture. Additionally, with start-ups, it is not always clear which product(s) or service(s) will be successful, and there is little historical data on which to base a decision. That leaves management as the most concrete aspect for a VC to evaluate (though products and services will still be scrutinized). VCs consider the following when evaluating the cofounders and leadership teams:

- Characteristics: successful management team members are people who are entrepreneurial, motivational, flexible, determined, committed

Francesco De Rubertis is a partner and Roman Fleck is a principal at Index Ventures, Geneva, Switzerland. Werner Lanthaler is CEO at Evotec AG, Hamburg, Germany.

e-mail: Francesco@indexventures.com

\begin{tabular}{|c|c|}
\hline Factor & Strategy \\
\hline Management & $\begin{array}{l}\text { Build a team that shares an ambitious common vision, intellectual honesty and an } \\
\text { entrepreneurial culture in which the driving founders have a long-term commitment }\end{array}$ \\
\hline Ability to adapt & Stick to your vision, but be prepared for your original business plan to change \\
\hline Timing & Where is the market going to be in seven years' time? You should know the answer \\
\hline Location & Choose somewhere accessible that will raise your equity value \\
\hline Cash & Attract venture capitalists from day one \\
\hline Science & $\begin{array}{l}\text { Make sure your science is world class, but remember: science alone does not make } \\
\text { a successful company }\end{array}$ \\
\hline
\end{tabular}

and energized. Combined with leadership ability, management teams with these characteristics help drive a company forward and exploit opportunities.

- Employees: getting the most out of employees is vital to the success of your business-you want to attract and retain the best people. Management must also be open to new ideas and suggestions.

- Experience: good management will be familiar with many positive and negative situations (both internally and externally), which means they will be able to make decisions quickly and respond effectively.

- Networks: well-connected management teams have access to cash, strategic advice, information, markets and opportunities.

- Success: management teams with a record of success are more likely to attract VCs and greater amounts of cash. They also understand what makes a successful company and how to run one.

Consider the top 20 biotech companies across the United States and Europe. The management teams at those firms all possess the above elements. Although assets and technology drive overall market value, having the right management team (usually based around 3-4 cofounders) and cash from the very beginning is key to success. You should form your management team to be ready to adapt and evolve. Your team must be able to absorb failure and learn from disappointments.

Two other factors play a critical role in forming companies that earn long-term success. First, the quality of the original idea and founding vision behind the company's formation must always remain constant-even when the business grows larger and adapts to change. Second, the original founders and entrepreneurs should remain and lead the company through the inevitable peaks and troughs. Although the founders' roles and responsibilities will no doubt change, founders tend to confer the same enthusiasm and passion that they did when they first set up their business, which keeps an entrepreneurial spirit at the heart of the company. A good example is Actelion in Allschwil, Switzerland, which still has its original founders involved in the goings-on of the company. 


\section{Evolve or die: adapting your business}

One of the main reasons biotech companies fail is because they believe they have the best potential drug and that the world will adapt to accommodate their business. They assume that they will be able to hire the best people, raise the most cash and make lots of money. This couldn't be further from the truth. Other than perhaps Genzyme, of Cambridge, Massachusetts, very few companies got their drug right the first time.

This is why the majority of the world's top biotech companies are very different today compared with their formative years. Their original products and/or technology were shelved or deprioritized as they quickly adapted and evolved to changing market forces and consumer needs. Amgen, of Thousand Oaks, California, for example, was formed to capitalize on recombinant DNA and genetic engineering. It wasn't until years later that it focused on erythropoietin, which brought in billions of dollars. Another example is Millennium Pharmaceuticals, of Cambridge, Massachusetts, which even though it was originally founded as a genomics company, bought Leukosite (a Cambridge, Massachusetts-based company developing therapeutics for cancer, autoimmune and inflammatory disease) in a stock-for-stock deal worth about $\$ 635$ million. This ultimately led to the approval of the new ubiquitin proteasome inhibitor Velcade (bortezomib) and an investment in an oncology drug pipeline, transforming Millennium into a drug company. That led to Osaka, Japan-based Takeda buying Millennium in May 2008 for $\$ 8.8$ billion.

Founders who have established long-term, sustainable companies understand that they will, at some point, need to adapt or evolve their business model. It's a tough decision, but they mark pivotal moments in a company's history. When choosing whom to invest in, VCs look for management teams that completely understand a business and are fully committed to it, that demonstrate the ability to quickly terminate unsuccessful projects and that are able to absorb failure, adapt and move on. Successful founders are able to articulate their reasons rationallywhile remaining true to their original vision.

Arguably, those types of entrepreneurs are able to win the renewed backing of their investors, thus setting the stage for their businesses to adapt and evolve as necessary. Possessing both the clarity and conviction to make (and follow through on) tough decisions early and the strength to commit to entrepreneurial ventures have been common features of the start-up teams at Genzyme; Gilead in Foster City, California; Millennium; and Genentech in South San Francisco. They didn't just have the right science-their management teams were capable of absorbing failure and changing it into opportunities. When you start your own firm, be sure you do the same. A key will be not throwing good money after bad.

Currently, fewer than 15 companies in Europe have a market capitalization equal to or more than $\$ 500$ million. Of those, only three have passed the $\$ 1$ billion threshold-Actelion, Intercell in Vienna and Genmab in Copenhagen. Most of those companies were formed in the mid- to late nineties, largely by the same entrepreneurs running them today. Again, most of them have gone through remarkably similar changes and evolution in their business plans, seen their leading assets fail and, in some cases, witnessed their share price plummet by $70-80 \%$ in a single day. Yet they have returned stronger and well positioned to grow back.

\section{Timing: predicting the future}

Some people argue that timing is luck and that you can't plan for things. They are wrong. You can plan, but only if you are open-minded and position your start-up correctly. For example, the Human Genome Project created huge excitement, and companies that were founded two or three years before the project were well supported by the market. Also, consider that in the early 1990s nobody was looking at antibodies, but from 1998 onward they became huge. Timing can be everything and a real determinant of success.

Good founders, entrepreneurs and management teams will be able to take a macro view and predict how the industry (or a particular sector) will develop and what it will look like in 5-7 years. The rule of thumb is that it is easier to predict how a market or sector will develop during the next few years than it is to predict the destiny of your drug or molecule. If antibodies are going to be valuable for the next decade, ask if your company should be developing alternative platform technologies, new delivery routes or generics. Always look ahead.

Roche in Basel, Switzerland, for example, is well positioned for the near future because of two visionary decisions taken by the company's management several years ago: significant exposure to biologicals (antibodies in particular) and diagnostics. The judgments were based on the conviction that these areas would become major growth drivers in the industry, and Roche is now reaping the rewards of those decisions. But there will always be the long term, and Roche's management is deciding what it needs to do now for the company to remain competitive.

\section{Location: choose wisely}

If you are building a business from scratch, a key objective is to minimize the number of risks to potential investors. One such risk is the location of your company. Although you may think that setting up your company in lush countryside will provide your employees with a tranquil setting that encourages free thinking and innovation, potential investors will be shaking their heads in dismay at the distance they must travel. Following a few simple rules can ensure your choice of location and increase both investment and, ultimately, long-term equity value.

Biotech start-ups should locate near established firms for many reasons. Clustering has several advantages: first, it enables companies to be tuned into an industry's strategic shifts and become successful together; second, it provides an environment that will attract world-class talent-recruits have the security of knowing that if things don't work out with one company then there are others nearby; third, it allows mixing of skill sets, and many important discoveries and scientific advancements have come from the convergence of different disciplines and cultures.

Only a few global geographic centers have succeeded in establishing solid biotech clusters. In the United States, these include San Francisco's Bay Area and the Boston/Cambridge axis in Massachusetts. In Europe, the clusters are less concentrated, but include the UK's Golden Triangle of Oxford, Cambridge and London; the Basel/Zurich region in Switzerland; Munich/ Martinsried in Germany; and the Medicon Valley in Sweden/Denmark.

Biotech, more than almost any other hightech business, depends on close ties with leading academic institutions both at inception and for continued survival. More often than not, critical technologies are discovered and developed in academia. Close personal and professional relationships between industry and academia provide the main source for the most promising ideas. Quite frequently, universities also provide initial staff for biotech companies, in the form of consulting professors, graduate students and postdoctorates participating in the research that produced the commercial ideas.

Location can also play a critical role in exit strategies. Take the example of Ribopharm in Kulmbach, Germany, and Alnylam in Cambridge, Massachusetts - two world leaders in therapeutic RNA interference. For Ribopharm, although it had critical parts of the technology and very compelling intellectual property, it was unable to create critical mass partly due to its location, and it became attractive to rival suitors. In the end, Alnylam, located in a biotech hotspot and owning comparable intellectual property and technology, bought Ribopharm and became the dominant player in the RNA interference space. 


\section{Cash: VCs equal success}

Drug discovery and development is very capital intensive-companies need to invest hundreds of millions of dollars before they can start generating profits. Unfortunately, financing is probably the greatest risk companies face in their early stages. A common feature of successful biotechs has been their financing strategies and the investment from VCs. The earlier you can get VC backing, the greater your chances of success.

VCs have, from an early stage, backed about $60 \%$ of current public European biotechs at some point. Late-stage investors, private equity funds, bankers and institutional investors often use the presence of blue chip VCs as a first-selection criterion to identify potential start-ups in which to invest. Venture capital can be seen as the very first bit of leverage that an entrepreneur may possess-essentially a key strategic tool. Serial entrepreneurs who have previously accessed venture capital recognize this and are more likely to look for venture capital earlier than first-time entrepreneurs. One very fair concern of entrepreneurs is that VCs often pay attention to only a few 'value drivers' in the company's portfolio while neglecting the remaining assets. Although this 'forced focus' may seem to be a limitation on the early aspirations and vision of entrepreneurs, in reality this strategy does not rule out pipeline expansion and diversification of the asset base. It instead focuses limited early investment on reaching major inflection points that allow further financing at a more attractive cost of capital.

And you should look to VCs right from the outset. Bringing in VCs gives you access not only to cash but also to advice, information, market knowledge and networks. The VCs can help you build the company, make it more financially attractive to other potential investors and increase the chances of your company going public. Essentially, the VC acts as a founding partner and gives you a solid financial platform from which to build your company.

When you do look for money, don't try to play VCs against each other to gain more investment for less equity. VCs know what they are talking about, they understand the market and will do their utmost to raise the value of your company. It is best to stick to one or two VCs that you trust, have previously worked with or that have been recommended. The VC you

\section{Box 1 Growing up Intercell AG}

I was the former Chief Financial Officer at Intercell in Vienna, a developer of antigens, adjuvants and vaccines. To grow the business, the company's management followed many of the principles discussed in this article. Founded in 1999 as an academic spin-off of the University of Vienna and the Institute of Molecular Pathology in Vienna, founders Alexander von Gabain and Max Birnstiel left academic jobs to focus on the company. The company raised more than $€ 150$ million (about $\$ 201$ million) before listing on the Vienna stock exchange in 2005 and achieved profitability in 2007, even before selling its first product. How?

Success came from having the right blend of skills and experience, and making the most of opportunities. It also helped that the company had the same management team for almost nine years.

In the early years, Intercell was able to attract venture capitalist money by having a modest valuation and by seeking out venture capitalists that complemented the business and direction. In some cases, investment was rejected because the founders felt the investors were not a good fit for the company. The management team also leveraged the company's platform to score meaningful partnerships with several global pharmaceutical companies, including Novartis in Basel, Switzerland; Merck in Whitehouse Station, New Jersey; Wyeth in Madison, New Jersey; Sanofi Pasteur in Lyon, France; Kirin in Tokyo and the Statens Serum Institut in Copenhagen. Many biotechs think that you only need products to be successful and that partnering is a bad idea-that you're giving away your secrets and value. Part of Intercell's success resulted from partnering: it was a smart way of early risk diversification.

Finally, when the company beat the odds and had success with its first product, the seasoned management team was prepared. It's no use having a product and not knowing what to do with it. The team at Intercell was lucky because the first product was successful. But you create your own luck-and I and the other members of Intercell's team saw an opportunity and capitalized on it.

choose will be your long-term partner in building your company.

Of course, it helps if your business generates cash, because that decreases the dependence on equity and/or debt financing. Most companies will not have a revenue-generating profit stream early on. Forming strategic alliances with corporate partners as soon as possible can provide valuable endorsement in addition to financial support. However, it is important to weigh the long-term implications of such deals. Generous up-front and milestone payments can be to the detriment of downstream royalties as well as providing a hurdle in the event of a business sale. The distance, measured in cash, to independence from equity fund raisings is a key parameter in evaluating the attractiveness of an investment and its intrinsic level of risk.

\section{Conclusions}

Starting a sustainable biotech company means having the right blend of management, access to cash, adaptability, timing and location. By recognizing, leveraging and capitalizing on all the possible opportunities, you will give yourself a head start on the road to building a successful company. After all, although it can be done (Box 1), starting a biotech business from scratch and developing it into a truly global player that can evolve and adapt with the industry is something that almost defies natural selection in today's competitive market. So don't focus all your energy into a drug that most likely will not succeed; rather, look to build a unique business, with great science, that is forward-looking and can adapt to the market several years from now. This will make your company more attractive to VCs at an earlier stage because you are minimizing investors' risks.

With these elements, combined with a long-term vision, an entrepreneurial spirit, good management, drive and passion, you will possess the keys to having a successful biotech company. 